\title{
消波ブロック被覆堤の最下層に設置される ブロックに作用する上載荷重に関する 実験的研究
}

\author{
昇 悟志 1 -久保田 真一 2 - 松本 朗 $3 \cdot$ 千 和 伸浩 4 - 岩波 光保 5 \\ 1 正会員 株式会社不動テトラ 総合技術研究所 材料・構造研究室 \\ ( (300-0006 茨城県土浦市東中貫町 2-7) \\ E-mail: satoshi.noboru@fudotetra.co.jp \\ 2 正会員 株式会社不動テトラ 総合技術研究所 水理研究室（テ300-0006 茨城県土浦市東中貫町 2-7） \\ E-mail: shinichi.kubota@fudotetra.co.jp \\ 3 正会員 株式会社不動テトラ 総合技術研究所（テ300-0006 茨城県土浦市東中貫町 2-7） \\ E-mail: akira.matsumoto@fudotetra.co.jp \\ 4 正会員 東京工業大学准教授＼cjkstart環境・社会理工学院（干152-8552 東京都目黒区大岡山 2-12-1） \\ E-mail: chijiwa@cv.titech.ac.jp \\ 5 正会員 東京工業大学教授 環境・社会理工学院（干152-8552 東京都目黒区大岡山 2-12-1） \\ E-mail: iwanami@cv.titech.ac.jp
}

消波ブロックの構造性能の評価手法を確立するために, 消波ブロック被覆堤を対象に消波ブロックに作 用する荷重の中でも最下層に設置するブロックに作用する上載荷重に着目し, 荷重の分布特性や波浪によ る変動荷重の特性を明らかにするとともに, 荷重の定式化の可能性を探ることを目的に, 上載荷重の測定 実験を静穏下ならびに波作用下で実施した。 その結果, 静穏下における最下層ブロックに作用する上載荷 重はガンマ分布で近似でき, 波作用下における変動荷重は越波時と非越波時で傾向が変化する特性を有し ていることが明らかとなった。また, 静穏下の上載荷重ならびに波作用下の変動荷重を定式化した.

Key Words: wave-dissipating concrete block, surcharge load, breakwater covered with wavedissipating concrete blocks

\section{1. はじめに}

日本国内の港湾・漁港施設や海岸施設等には数多くの 消波ブロックが用いられている. 目的は施設に作用する 波力や反射波，および施設を乗り越える越波量の低減等 であり，代表的な施設として，図-1 に示した消波ブロ ック被覆堤がある。

現在，このような施設に用いられる消波ブロックの規 格（ブロックの種類，大きさ）は，質量算定の基本式 （ハドソン式）や水理模型実験等による而波安定性およ び消波機能（反射率，伝達率等）の評価，および経済性 等によって決定される.

一方，ケーソン前面の消波工に置かれた消波ブロック には，その上層に積まれる消波ブロック群による荷重 （以降，上載荷重と呼ぶ）が作用する（図-2）。この荷
重は静穏時の死荷重と, 波浪による変動荷重の組合せに なると考えられる.

また，波浪の繰返しによって表層の消波ブロックが不 安定な状態となり，小さな回転運動や移動，およひ転落 等を起こして隣接する消波ブロック等に衝突することに よる衝撃荷重も作用する（図-3）。この荷重は衝突時の 速度に依存すると考えられる。

現在, 国内で使用されている消波ブロックの大半は無 筋コンクリートである. ゆえに, 上載荷重や衝撃荷重に よって一度ひび割れが発生すればブロックの損傷が一挙 に進行し，場合によっては連鎖的に周囲のブロックの損 傷を誘発する可能性がある，その損傷は，消波工の沈下 や散乱，またはケーソンの損傷を引き起こし，結果的に 港内の静穏度が低下し, 港湾の機能が損なわれる可能性 がある.よって，消波ブロックがこのような作用に対し 


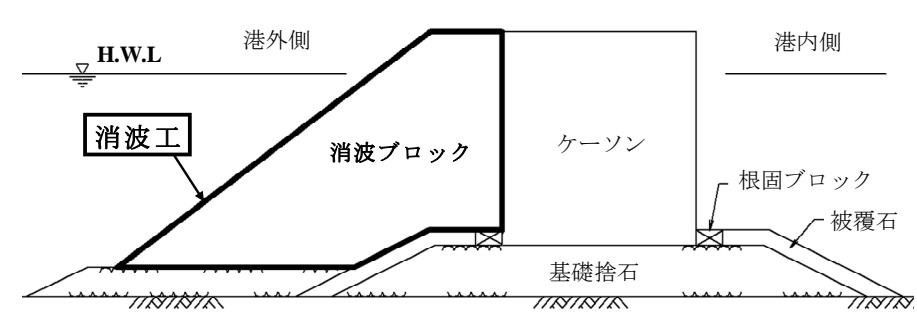

図-1＼cjkstart消波ブロック被覆堤（例）

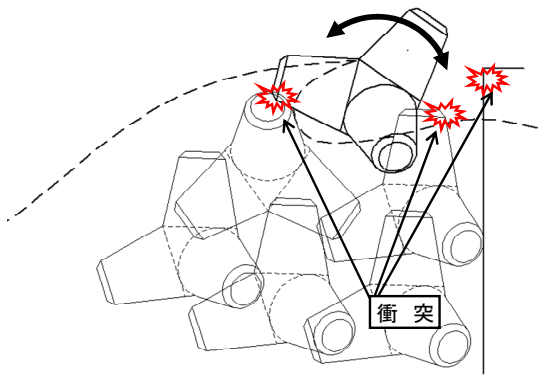

図-3＼cjkstart消波ブロックの動摇と衝突

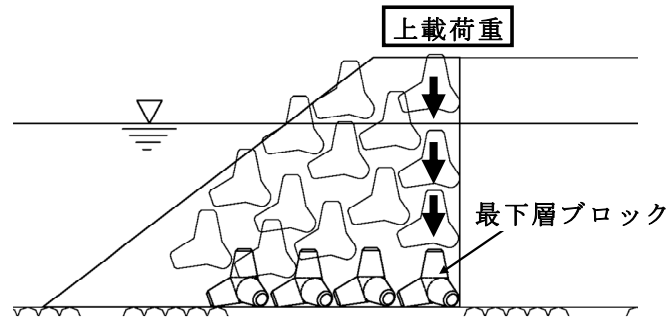

図-2 上載荷重

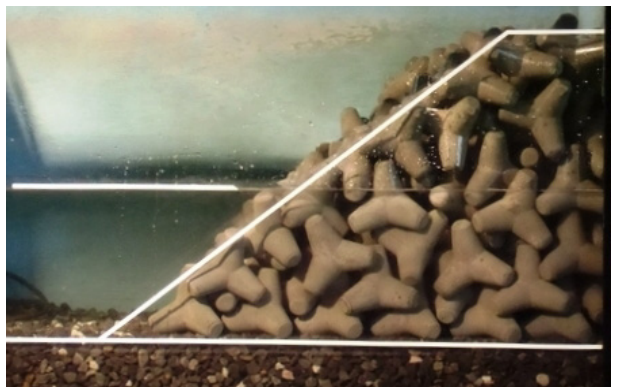

図-4 消波ブロックの不規則的な配置
て十分な構造強度を有することは重要であるが，現状は 消波ブロックの規格決定に構造強度の評価はほとんど反 映されていない，上述した質量算定の基本式や水理模型 実験等による評価については, ブロックの種類に関わら ず同一尺度で評価できる手法が確立されているものの， 構造強度に関しては未だに評価手法が確立されておらず, 経験的な評価（判断）に留まっている. これが確立され れば，耐波安定性と構造強度の両面から消波ブロックの 種類や大きさを合理的に決定することができ，結果的に 港湾の機能をこれまでよりも長期に亘り確実に維持でき るものと考えられる.

消波ブロックの構造強度の評価手法を確立するために は，消波ブロックの耐荷力の評価と作用の設計值が必要 となる．特に作用は設計值を設定する以前に，上載荷重 の特性や，波浪による繰返し衝突時の衝撃荷重および衝 突速度の特性を明らかにしなければならない. 上載荷重 に関しては，著者ら ${ }^{1)}$ がある特定のブロックを対象とし て測定実験を実施している. しかし，この実験は完全に 気中状態でのものであり, 水位の影響や波浪による変動 荷重の影響は検討されていない，また，消波ブロックの

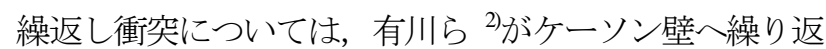
し衝突する消波ブロックの衝撃荷重や衝突速度に関する 研究を行っているが，規則波を対象とした実験であり， その波高や周期が限定されている. また，山口ら ${ }^{3)} も$ 消 波ブロックの衝突に関する研究を行っているが，繰返し 衝突を対象としたものではない. よって，いずれの研究 も，消波ブロックの作用の特性を明らかにするには至っ ていない.

そこで本研究では，消波ブロック被覆堤を対象に，上
述した作用の中でも消波工の最下層に設置される消波ブ ロックに作用する上載荷重に着目し，その荷重の分布特 性や波浪による変動荷重の特性を明らかにするとともに, 上載荷重の定式化の可能性を探ることを目的に，消波ブ ロック模型を用いた上載荷重の測定実験を実施した.

なお，波浪による繰返し衝突時の衝撃荷重と衝突速度 の特性や，消波ブロックの耐荷力評価については，別途 著者らによる検討を現在行っている.

\section{2. 静穏下の最下層ブロック単体に作用する上載 荷重}

消波工に用いられるブロックは，図-4 のように最下層 については規則的に配置され，その上方は不規則的に配 置されるのが一般的である. よって，その不規則性によ り最下層のブロック群に均等な上載荷重が作用するとは 考え難く，あるばらつきを持つ分布となり，その分布は ブロックの形状や大きさおよび測定対象の最下層ブロッ クの設置位置により異なるものと推測される。しかしな がら，その荷重分布の平均值は図-5 の荷重モデルを用い て式(1)のような形式で表すことができるものと考えら れる.

$$
\begin{aligned}
& P_{c}=\rho_{B} g S h-W^{\prime} \\
& \quad \text { ただし, } \rho_{B}=(1-p / 100)\left\{\rho_{c}-\rho_{w}\left(h_{s} / h\right)\right\}
\end{aligned}
$$

ここで， $\rho_{\mathrm{B}}$ は消波工の見かけの密度， $g$ は重力加速度， $S$ はブロック 1 個の支配面積, $h$ は消波工の高さ, $p$ は空 隙率， $\rho_{c} お よ ひ ゙ \rho_{w}$ はブロックおよび水（または海水）の 
密度， $h_{s}$ は消波工の水面下の高さ，W'は最下層ブロック の重量である．また， $S$ は消波工下端の単位幅（単位延 長）あたりの全面積を，その延長に設置される最下層ブ ロックの個数で除した值である. $W^{\prime} は$ 気中の場合は $\rho_{c} v$ $(v:$ ブロック単体の体積 $)$, 水中の場合は $\left(\rho_{c}-\rho_{w}\right) v$ であ る.

この式(1)は, 最下層ブロックに作用する上載荷重が, 消波工全体の見かけの密度や浮力, 消波工の高さ, 最下 層に配置されるブロックの個数に依存すると仮定して導 いている. また，比較的簡便な式であり，ブロックの形 状が異なっても適用できる形式を取っている.

そこで，ブロックの形状や測定対象とする最下層ブロ ックの位置，およびブロックの大きさが上載荷重分布に 及ぼす影響を測定実験にて調查するとともに，測定結果 と式(1)との比較も行った.

\section{（1）ブロックの形状が上載荷重分布に及ぼす影響}

まずはブロックの形状による上載荷重分布の違いを明 らかにするための実験を行った．実験は図-6の2 種類の 消波ブロックを用いた．模型縮尺は $1 / 56$ とし，表-1 に 示寸諸元の模型を使用した。この場合のブロック質量の 現地量は四脚ブロックが 83.4t, 楔形ブロックが 92.4t と なる。これらは，いずれも現在国内で使用されている消 波ブロックの最大クラスの条件である.

実験断面および測定装置を図-7 に示す．図中の消波 工高さ $400 \mathrm{~mm}$ は, 四脚ブロックの大型（50t 型～80t 型）の施工実績を調査して決定した。測定対象とした最 下層ブロックの位置は図中に示した鉛直壁（ケーソン） 前面（測定位置[A]）とし，奥行き方向には中央とした. 実験には模型台 $(H: 0.6 \mathrm{~m} \times B: 0.5 \mathrm{~m} \times L: 1.0 \mathrm{~m})$ を使用し， 測定ブロックの下面に樹脂製の台座を接着, その台座と ロードセル，およびロードセルと模型台底面は動かない よう固定した．また，ロードセルの周囲には石が入り込
まないよう板で仕切りを設け，捨石マウンド上面となる 箇所にサンドペーパーを貼り付けた蓋を被せ，測定位置 周辺の最下層ブロックが滑らないよう対策を講じた。 な お，蓋は台座周辺に切り込みを入れ，蓋と台座が接触し ないようにしている.

実験ケースは，完全な気中の状態で消波ブロックを積 み上げた場合（Case1）と，水位 $\left(h_{s}=200 \mathrm{~mm}\right)$ がある場 合および消波工が完全に没水した場合（Case2 および

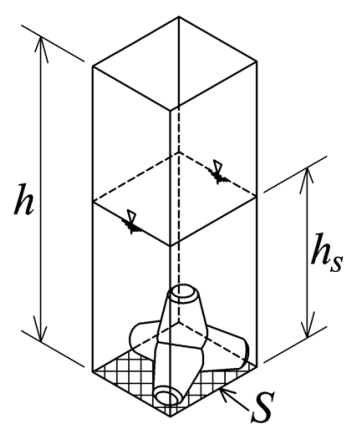

図-5 上載荷重モデル
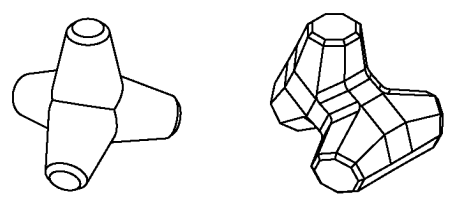

図-6 実験に使用したブロック（左図 : 四脚ブロック，右 図 : 楔形ブロック)

表-1 ブロック模型の諸元

\begin{tabular}{|c|c|c|c|c|}
\hline 名 称 & $\begin{array}{c}\text { 質量 } \\
M(\mathrm{~g})\end{array}$ & $\begin{array}{c}\text { 密度 } \\
\rho_{c}\left(\mathrm{~g} / \mathrm{m}^{3}\right)\end{array}$ & $\begin{array}{c}\text { 体積 } \\
v\left(\mathrm{~cm}^{3}\right)\end{array}$ & $\begin{array}{c}\text { 空隙率 } \\
p(\%)\end{array}$ \\
\hline 四脚ブロック & 474.8 & 2.374 & 200.0 & 50 \\
\hline 楔形ブロック & 526.2 & 2.321 & 226.7 & 51 \\
\hline
\end{tabular}
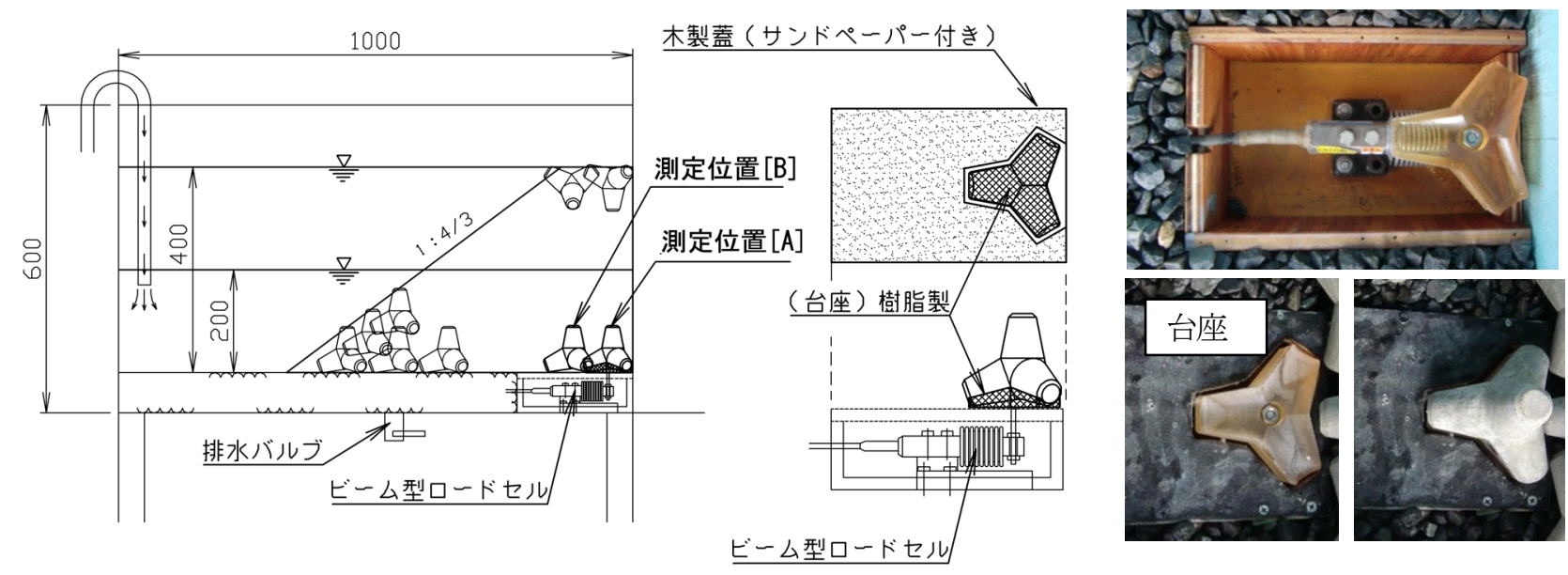

図-7 実験断面および実験装置（単位 : mm) 


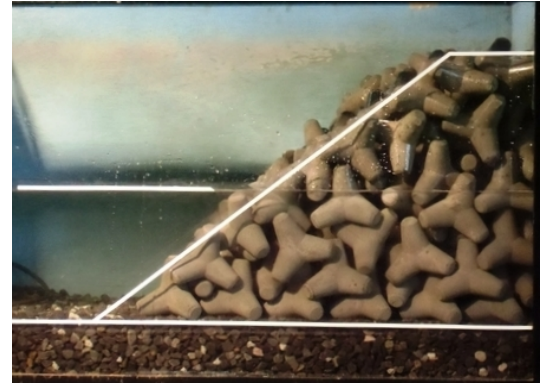

(a) 四脚ブロック (再掲)

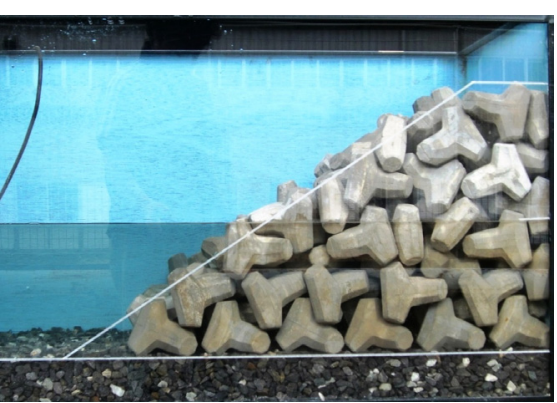

(b) 楔形ブロック

図-8 実験（積み上げ）状況

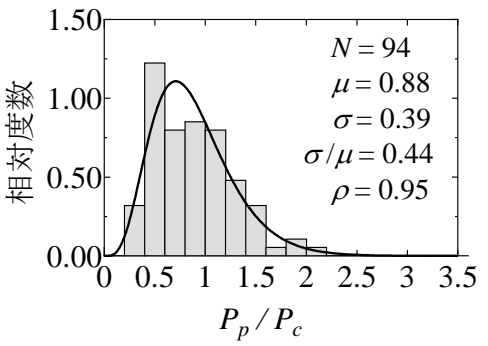

(a) Case1

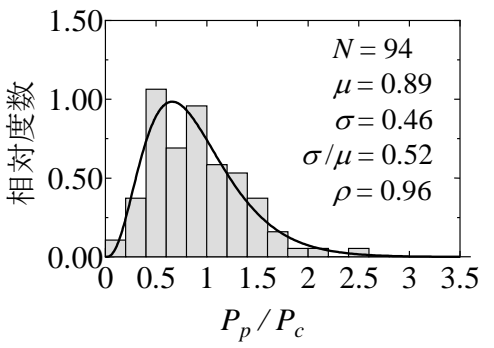

(b) Case2

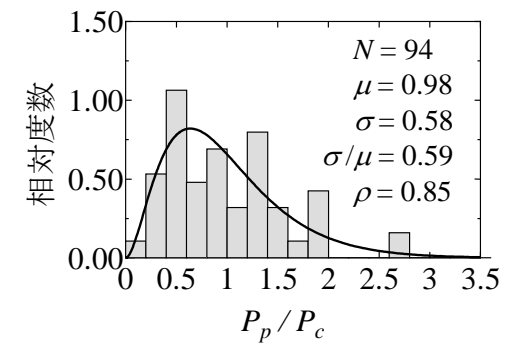

(c) Case3

図-9 四脚ブロック単体に作用する上載荷重（測定位置[A]）

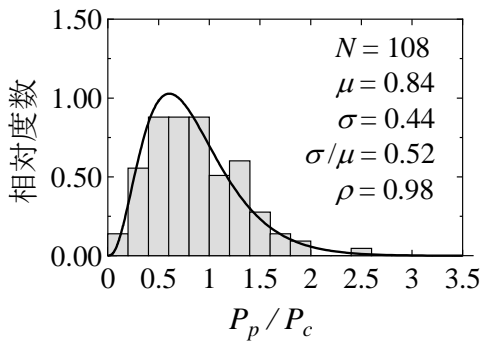

(a) Case1

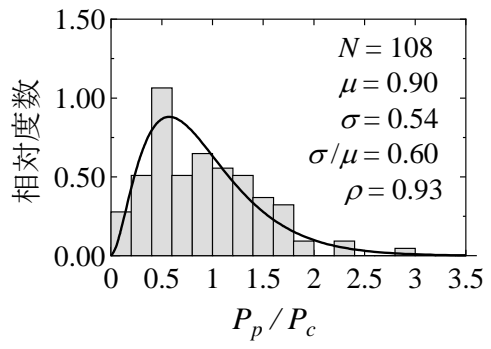

(b) Case2

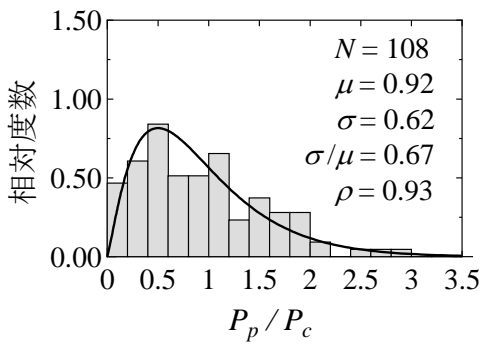

(c) Case3

図-10 楔形ブロック単体に作用する上載荷重（測定位置[A]）

Case3）の 3 ケースとした. 測定は Case1 $\rightarrow$ Case2 $\rightarrow$ Case3 を1サイクルとし，ケース毎に上載荷重を測定した。模 型を積み上げる前に荷重初期值をゼロとし，1 サイクル 終了後，測定対象ブロック以外の模型を撤去し，この状 態で再度初期值をゼロに戻し，模型を積み替える.この 一連のサイクルを 100 回程度繰り返した. なお，模型の 積み上げは実際の施工をできるかぎり模擬することとし， 1 層目は規則的な配置で並べ，2 層目より上層は，ブロ ック同士の隙間に，ブロックの脚を挿入していく方法を 基本としながらランダムに積み上げた（図-8）。

実験結果を図-9 および図-10 に示す。ここで, 図の横 軸は測定された荷重 $P_{p}$ を式(1)から計算された上載荷重 $P_{c}$ で無次元化している. 図の棒グラフは, $\Delta\left(P_{p} / P_{c}\right)=0.2$ 刻 みの階級毎の出現回数 $n$ と試行回数 $N$ を用いて無次元化 し，相対度数として表したものであり，実線（曲線）は ガンマ確率分布である。また， $\mu, \sigma, \sigma \mu, \rho$ はそれぞ れ荷重の平均值, 標準偏差, 変動係数, およびガンマ確
率分布と相対度数分布との相関係数である.

まず平均值に着目すると，ブロックの形状や実験ケー スに関わらず平均值は $P_{C}$ の 90\%程度であることがわか った.よって，上載荷重の平均值は式(1)にて評価でき る可能性があることが確認された.

次に変動係数に着目すると，その值は 40\%～70\%程度 と大きい. これは, 測定対象ブロックに接触している周 囲および直上に置かれたブロックの位置や姿勢（向き） が試行ごとに異なり，これにより測定対象ブロックへの 荷重伝達経路が異なるためと考えられる.

また，ケース毎に変動係数を比較すると，四脚ブロッ クと楔形ブロックともに Case $1 \rightarrow$ Case2 $\rightarrow$ Case3 の順に值 が大きくなっている，これは，水を注水していく（水位 が上昇する）に従って徐々に浮力が作用していき，これ によりブロック同士の接触状態に変化が生じ，この変化 のばらつきが Case1 の結果に付加されていったためと考 えられる. よって, 最初から水位のある状態からブロッ 


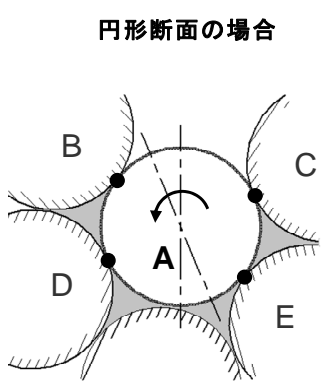

接触点や空隙は変化しない
多角形断面の場合

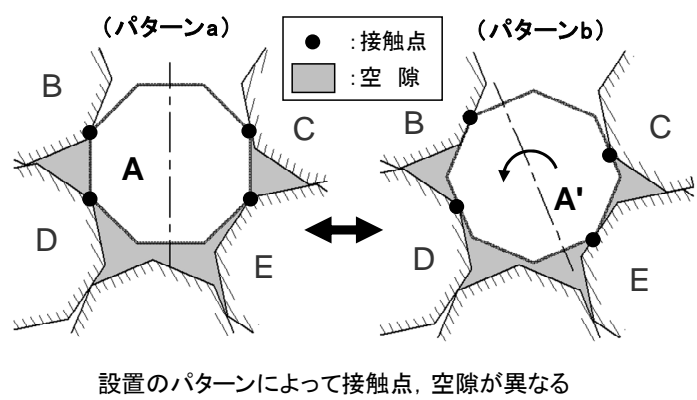

図-11 断面形状による周囲との接触状態の模式図

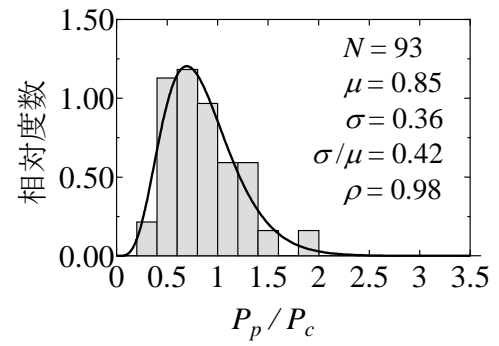

(a) Case1

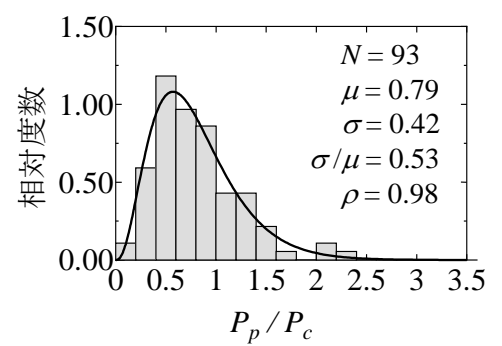

(b) Case2

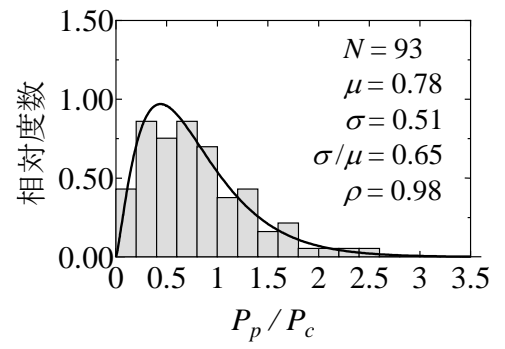

(c) Case3

図-12 四脚ブロック単体に作用する上載荷重（測定位置[B]，M=474.8g）

クを積み上げていけば Case1 の变動係数程度になるもの と推測される.

さらに，2 種類のブロックで変動係数を比較すると， すべてのケースで楔形ブロックのほうが值は大きい.こ れは2つの理由が考えられ，まずは，立体形状の違いで ある. 四脚ブロックは，重心から放射状に脚が伸びた形 状であり，重心を通る回転対称軸が楔形ブロックよりも 多い.よって，このような形状は積み上げ時に姿勢を回 転させても回転前の姿勢と同じになりやすい. これは, 積み上げ時の姿勢に方向性が出にくいことでもあり，積 み上げを繰り返しても同じような姿勢が再現されやすい ことにも繋がっている，その結果，試行による姿勢のば らつきが小さくなり, 四脚ブロックの変動係数が楔形ブ ロックよりも小さくなったと考えられる．次に，部材断 面が四脚ブロックは円形，楔形ブロックは八角形（多角 形）であることである. 図-11 に断面形状と周囲との接 触状態の模式困を示す，例えば同じ断面積の円柱を重ね 合わせる場合，円柱 $\mathrm{A}$ を断面の軸方向に回転させて置 いたとしても周囲の円柱 $\mathrm{B} \sim \mathrm{E}$ との接触状態やそれによ って生じる空隙は同じであり，これは試行ごとに変わら ない. しかし，断面が多角形の角柱であった場合，角柱 $\mathrm{A}$ がパターン a で置かれた場合とパターン b 状態で置 かれた場合では，周囲の角柱 $\mathrm{B} \sim \mathrm{E}$ との接触状態や，そ れによって生じる空隙は等しくならず，このパターンは 試行ごとに異なる。これと似た現象がブロックを積み重 ねる際の噛み合わせ状態にも起きており，断面形状の違 いが試行ごとのブロック相互の接触状態や個々の空隙の

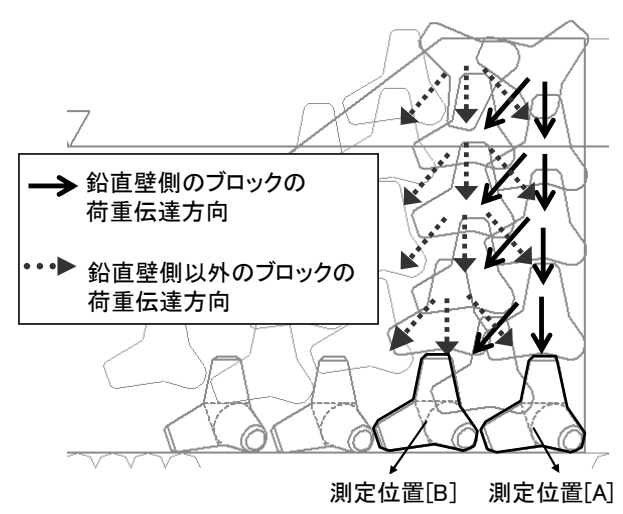

図-13 上載荷重の伝達経路模式図
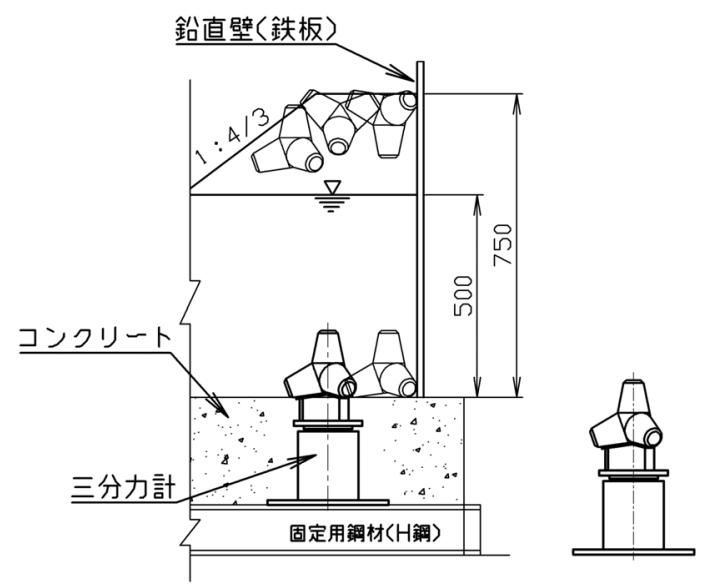

図-14 実験断面および実験装置（単位：mm）

ばらつきに差を生じさせ，これが上層ブロックから下層 
ブロックへ荷重が分散して伝達する際の伝達方向や荷重 伝達率のばらつきの差につながり, 上載荷重分布の変動 係数の差につながったものと考えられる.

確率分布との相関について，実験で得られた荷重の相 対度数分布と 4 種類の仮定した確率分布（正規分布，対 数正規分布，レイリー分布，およびガンマ分布）で両者 を検定した結果, ブロックの種類や測定ケースに関わら ずガンマ分布が最も相関が高かった。 よって，上載荷重 分布はこの関数形で近似できるとした.

以上の考察より, ブロックの形状は上載荷重分布の変 動係数に影響するものの，その分布はガンマ確率分布で 近似でき，また平均值は式(1)からおおむね推定できる ことが明らかとなった。

\section{（2）ブロックの測定位置が上載荷重分布に及ぼす影響}

次に, 最下層ブロックの位置による上載荷重分布の違 いを調べるため，鉿直壁から 2列目の位置（図-7 の測定 位置[B]）の上載荷重を測定した。この実験は表-1 の諸 元の四脚ブロックについて実施した. 実験断面や実験ケ 一ス，および測定方法は前節(1)と同様である.

測定結果を図-12 に示す。この実験においても上載荷 重分布はガンマ確率分布が実験結果に対して相関が最も 高かった。

図-9 の結果と比較すると, 標準偏差や変動係数に差 は見られないものの, 平均值が 10\%程度減少している.

これは荷重の伝達経路が測定位置[A]と違うためと考え られる. 図-13 に荷重伝達経路の模式図を示す．鉛直壁 側に置かれたブロックは，仮に壁面との摩擦が無いと仮 定すれば壁面側に荷重は分散されない，一方，鈆直壁以 外は周囲のブロックと噛み合っているため下層ブロック の全方向に分散されて伝達される. 鉛直壁側は, 周囲と の噛み合わせの無い面が存在するため, 測定位置 $[\mathrm{A}] の$ 上載荷重の平均值が測定位置[B]よりも大きくなったと 考えられる.このことから，鉛直壁側とそれ以外では上 載荷重分布はガンマ確率分布でともに近似できるが，平 均值に違いがあることが明らかとなった。

\section{（3）ブロックの大きさが上載荷重分布に及ぼす影響}

上載荷重は，ブロック相互のかみ合わせによる接触を 介して最下層ブロックに伝達されるため, 接触面の表面 粗さ（凸凹）によってかみ合わせによる接触状態は変化 すると考えられる.

模型と実海域に使用されるブロックの材質は同じであ るため, 表面粗さは同じである. しかし，実海域のブロ ック寸法は模型よりも大きいため, ブロック寸法に対す る表面粗さの割合は実海域ブロックの方が小さくなる. これは見かけ上，実海域ブロックの表面粗さが小さくな る（表面が滑らかになる）と考えることができるため,
表-2 ブロック模型の諸元

\begin{tabular}{|c|c|c|c|}
\hline $\begin{array}{c}\text { 質量 } \\
M(\mathrm{~g})\end{array}$ & $\begin{array}{c}\text { 密度 } \\
\rho_{c}\left(\mathrm{~g} / \mathrm{m}^{3}\right)\end{array}$ & $\begin{array}{c}\text { 体積 } \\
v\left(\mathrm{~cm}^{3}\right)\end{array}$ & 縮尺 \\
\hline 2,950 & 2.345 & 1,258 & $1 / 30$ \\
\hline
\end{tabular}

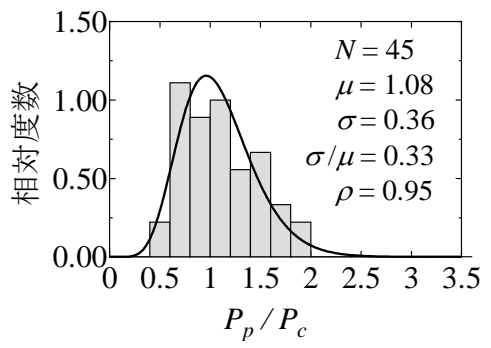

(a) Case1

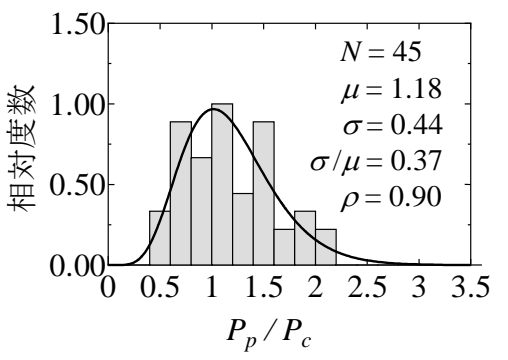

(b) Case2

図-15 四脚ブロック単体に作用する上載荷重（測定位置[B], $M=2,950 \mathrm{~g})$

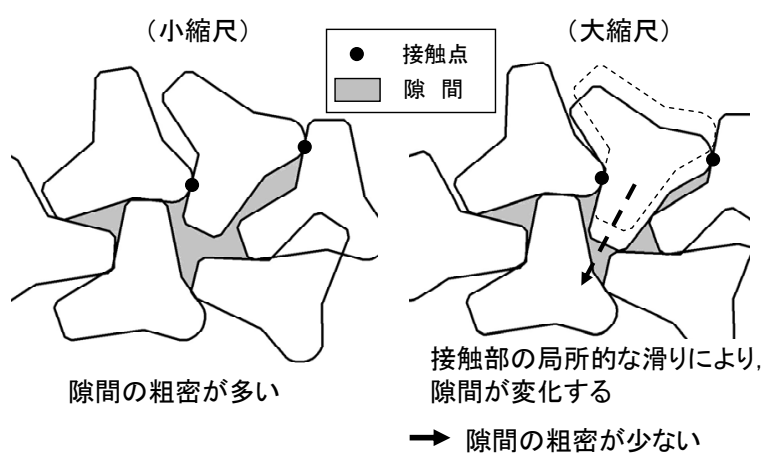

図-16 ブロック相互の接触状態と空間（空隙）

表-3 ブロック模型の諸元（Case4，Case5）

\begin{tabular}{|c|c|c|c|}
\hline $\begin{array}{c}\text { 質量 } \\
M(\mathrm{~g})\end{array}$ & $\begin{array}{c}\text { 密度 } \\
\rho_{c}\left(\mathrm{~g} / \mathrm{m}^{3}\right)\end{array}$ & $\begin{array}{c}\text { 体積 } \\
v\left(\mathrm{~cm}^{3}\right)\end{array}$ & 縮尺 \\
\hline 662.6 & 2.395 & 276.7 & $1 / 50$ \\
\hline
\end{tabular}

ブロック相互のかみ合わせによる接触状態が変化し，こ れが上載荷重分布に影響を及ぼす可能性がある.

そこで，大縮尺による上載荷重測定実験を実施し，ブ ロックの大きさが上載荷重分布に及ぼす影響を調査した. 実験縮尺は，図-7 の消波工断面を約 2 倍（縮尺 1/30） にし，図-14 のような実験断面と実験装置とした. 使用 したブロックは表-2 の質量 $M=2,950 \mathrm{~g}$ の四脚ブロックと 
し，測定位置は図-7 の測定位置[B]とした．また，測定 ケースは Case1（完全気中状態）および Case2（水位が ある場合）とした．縮尺を大きくしたことから，測定は 高さ $1.0 \mathrm{~m}$ ，幅 $1.0 \mathrm{~m}$ ，長さ $5.0 \mathrm{~m}$ のコンクリート壁で囲ま れた水槽内に三分力計を設置し，その上に測定ブロック を固定して行った.

実験結果を図-15 に示寸. 図の確率分布形はガンマ確 率分布である. 同じ測定位置で実験縮尺 $1 / 56$ で行った 結果（図-12）と比較すると，確率分布が図-12 の結果よ りも図の右側へシフトし, 平均值は Case1 で約 1.3 倍, Case2 で約 1.5 倍に増加したものの, 変動係数は Case1 で 20\%, Case2 で 30\%減少し, ばらつきは小さくなった. また，相対度数分布を見ると，最大值付近の相対度数に 大きな差はなかった。

これらの理由を図-16 を用いて説明する．大縮尺のブ ロックは見かけ上の表面粗さが小さくなり，接触点近傍 で局所的な滑りが生じる。これによりブロックは隙間に 入り込むように滑り込む．よって，大縮尺ではブロック 同士の接触によって形成される隙間の粗密が少なくなり, より均一な隙間になりやすい. 隙間の粗密は上載荷重の ばらつきに影響すると考えられることから，隙間の均一 化が大縮尺模型の荷重平均值の増加と変動係数の減少に 繋がったと推測される.

\section{（4）ブロックの測定個数が上載荷重分布に及ぼす影響}

ブロック単体に作用する上載荷重分布をブロックの形 状や最下層ブロックの位置, および大きさの条件を変え て実験にて調査した結果，上載荷重分布の変動係数は 40\%〜60\%程度であった.

消波工に設置されるブロックの，ある延長当たりの総 個数は消波工断面積から定まるため, 最下層ブロック全 体に作用する上載荷重は, ブロック総個数の重量から最 下層に配置したブロックの個数分の重量を差し引いた值 と等しくならなければならない. よって, 最下層ブロッ ク単体ではなく複数体（以降，群体と呼ぶ）に作用寸る 上載荷重分布のばらつきは減少すると考えられる，そこ で, 最下層ブロック群体に作用寸る上載荷重分布を実験 にて確認することとした。

群体の実験は，表-3 の質量 $M=662.6 \mathrm{~g}$ の四脚ブロック を用い，同時に測定するブロックの個数は 6 体とした. 実験断面および実験装置を図-17 に示す，最下層ブロッ ク 6体は鉄板上に固定し，その鉄板を三分力計の上面に 固定した.

実験ケースは完全気中状態と水位 $\left(h_{s}=30 \mathrm{~cm}\right)$ を有す る場合の 2 ケースとし，それぞれ Case4, Case5 とした. 荷重の測定方法はこれまでの実験と同じである.

実験結果を図-18 に示す．ここで，横軸の上載荷重 $P_{p}$ の值は測定值を $1 / 6$ にし，ブロック 1 体あたりの荷重に

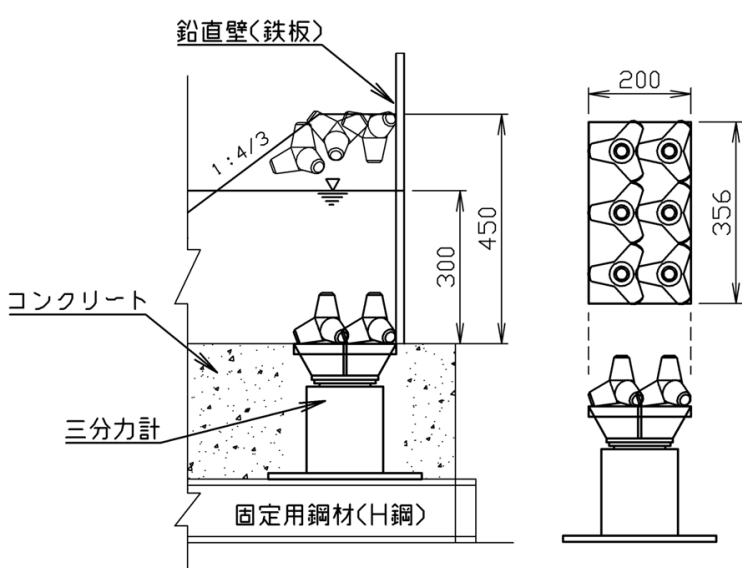

図-17 実験断面および測定装置（単位 : mm）

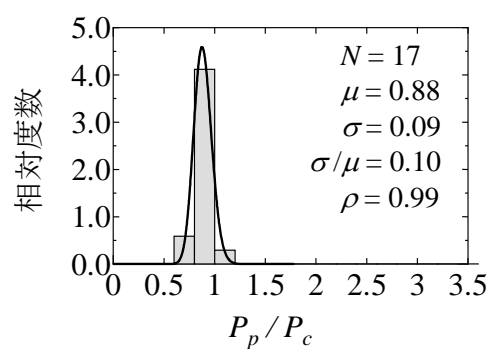

(a) Case4

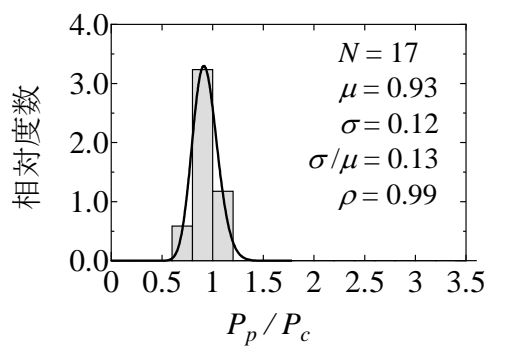

(b) Case5

図-18 四脚ブロック群体に作用する上載荷重 $(M=662.6 \mathrm{~g})$

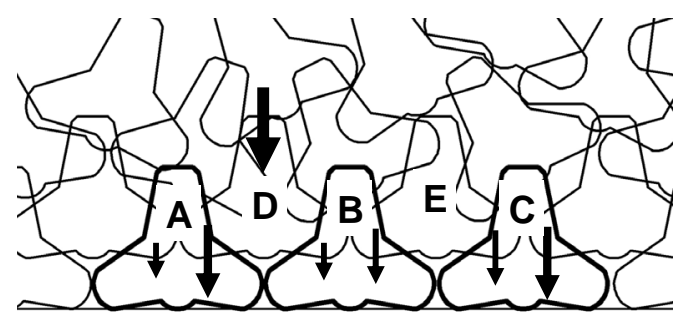

図-19隣接する最下層ブロックに作用する上載荷重

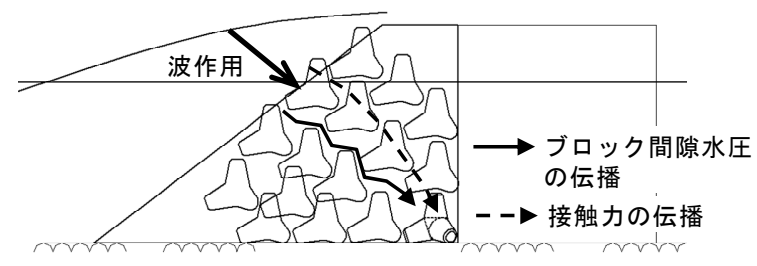

図-20 波力による接触力と間隙水圧の伝播 
置き換えている，また，図中の曲線はガンマ確率分布で あるが，変動係数が小さいため正規分布に近い形状とな っている.

両ケースを図-9 や図-12 のブロック単体の結果と比較 寸ると，実験の試行回数は少ないものの，平均值は同程 度であった．ただし，平均值からのばらつきは非常に小 さくなり, 変動係数は約 $10 \%$ と, ブロック単体の $1 / 4$ 程 度となった。 これは，個々のブロックは図-9 や図-12 の ような荷重分布であっても，ある最下層ブロックに着目 した時の試行の結果は，隣接するブロックの試行の結果 に影響を及ぼしていることを意味している．図-19 に示 すように最下層のブロックの上方のブロック $\mathrm{D}$ は，隣 り合う最下層ブロック A と B の隙間に設置される. ブ ロック $\mathrm{D}$ に伝達された上載荷重がブロック A およびブ ロック B に分散して伝達されるが，その荷重伝達率は 両者で等しくはない，ある試行で一方に作用寸る荷重が 大きければ，もう片方は小さくなる，ただし，その合計 はブロック D に伝達された荷重に等しくなる。よって, ブロック A の測定結果はブロック B に影響を及ぼすこ とになり，これが結果的に変動係数を大きく減少させた と考えられる.

\section{3. 波作用下の最下層ブロック単体に作用する上 載荷重}

波作用下においては，消波工の表層ブロックに波力が 作用し，その力が図-20 に示すようにブロックの接触を 介して最下層ブロックに接触力として伝播する。 また, 消波工内部ではブロック間隙水圧（以降，間隙水圧と呼 ぶ）が伝播する. よって，波作用下の最下層ブロックに は静穏下の上載荷重以外に接触力や間隙水圧による力も 付加されることになる．それらはある一定の荷重ではな く変動荷重として最下層ブロックに作用することになり, 上載荷重の設計用值を考える上では重要なものとなる.

そこで，最下層ブロックに作用する変動荷重の特性を 明らかにするため, 波作用下における荷重の測定実験を 実施した．なお，この研究での変動荷重の定義は，波作 用前の荷重（静穏時の上載荷重）をゼロとした場合の， 水位変動により増減する浮力の変動量, 波力による接触 力の変動量, および間隙水圧の力の変動量, これら $3 つ$ の合力を変動荷重としている.

\section{（1）実験断面および実験ケース}

実験は長さ $29 \mathrm{~m}$ ，幅 $0.5 \mathrm{~m} ，$ 高さ $1.0 \mathrm{~m}$ の造波水路内の モルタル床(1/30 勾配)上に, 図-21 の断面を設置して行っ た. 実験縮尺は 1/83.9 とし, ブロック模型は表-4 の諸元 の $M=139.9 g$ の四脚ブロックを使用した. また, 水面か

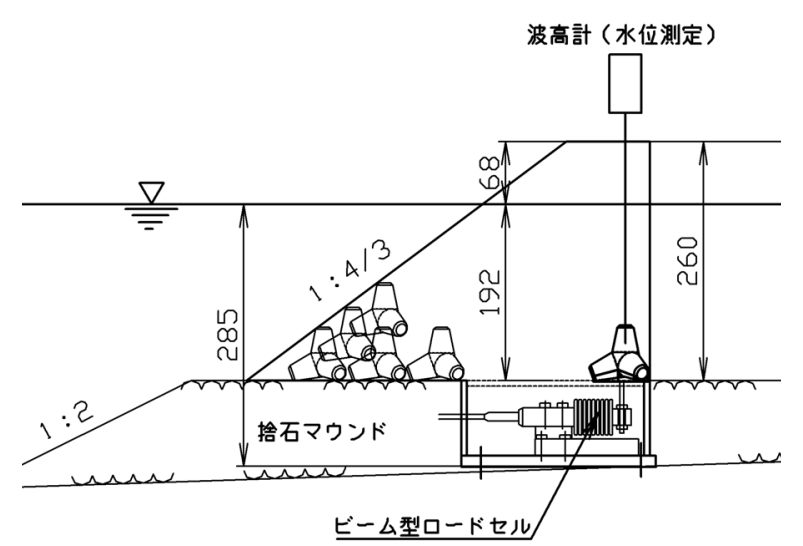

図-21 実験断面および測定装置（単位：mm）

表-4 ブロック模型の諸元

\begin{tabular}{|c|c|c|c|}
\hline $\begin{array}{c}\text { 質量 } \\
M(\mathrm{~g})\end{array}$ & $\begin{array}{c}\text { 密度 } \\
\rho_{c}\left(\mathrm{~g} / \mathrm{m}^{3}\right)\end{array}$ & $\begin{array}{c}\text { 体積 } \\
v\left(\mathrm{~cm}^{3}\right)\end{array}$ & 縮尺 \\
\hline 139.9 & 2.359 & 59.3 & $1 / 83.9$ \\
\hline
\end{tabular}

表-5 実験ケース

\begin{tabular}{|c|c|c|c|}
\hline 波浪種別 & 測定荷重 & $\begin{array}{c}\text { 周期 } \\
T(\mathrm{~s}), T_{13}(\mathrm{~s}) \\
\end{array}$ & $\begin{array}{c}\text { 波高 } \\
H(\mathrm{~cm}), H_{13}(\mathrm{~cm})\end{array}$ \\
\hline \multirow[t]{2}{*}{ 規則波 } & 変動荷重 & \multirow[b]{2}{*}{1.53} & \multirow[b]{2}{*}{$\begin{array}{c}\text { 2.5, 5.7, } 9.0 \\
11.3,15.0\end{array}$} \\
\hline & $\begin{array}{c}\text { 間隙水圧 } \\
\text { の荷重 }\end{array}$ & & \\
\hline 不規則波 & 変動荷重 & 1.53 & $5.7,9.0,11.3$ \\
\hline
\end{tabular}

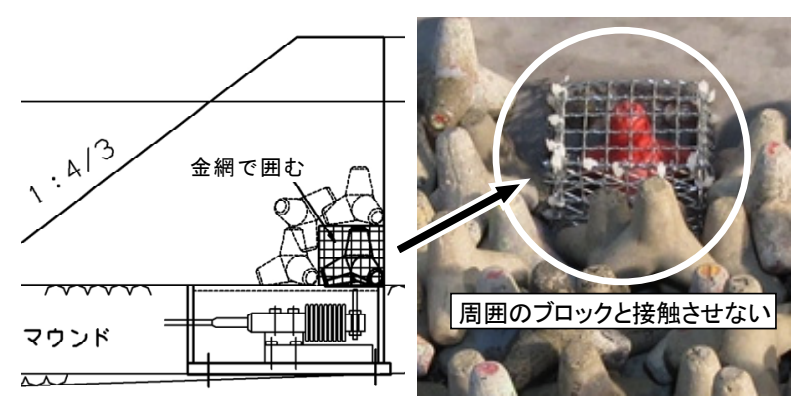

図-22 間隙水圧による荷重測定装置

ら消波工天端までの高さは，港湾施設の技術基準 4)参 考に，防波堤の安定の検討に用いる有義波高 $H_{13}$ の 0.6 倍とし， $H_{13}$ は四脚ブロックの大型（50t 型〜 80t 型）の 施工実績の調查結果からブロックの安定限界波高とした。 測定対象ブロックは鋁直壁（ケーソン）前面とし，延長 方向は中央とした。 また，測定装置は 2.(1)で使用した ものと同様としたが，水位変動との関係を調べるために 側面から見て測定対象ブロックの上向き脚中央の位置に 波高計を設置した.

実験ケースを表-5 に示す。測定は規則波と不規則波 とし，波高は規則波で $H=2.5 \mathrm{~cm} \sim 15.0 \mathrm{~cm}$ （現地量で約 $2.0 \mathrm{~m} \sim 12.5 \mathrm{~m})$ までの 5 種類，不規則波で $H_{13}=5.7 \mathrm{~cm} \sim$ 


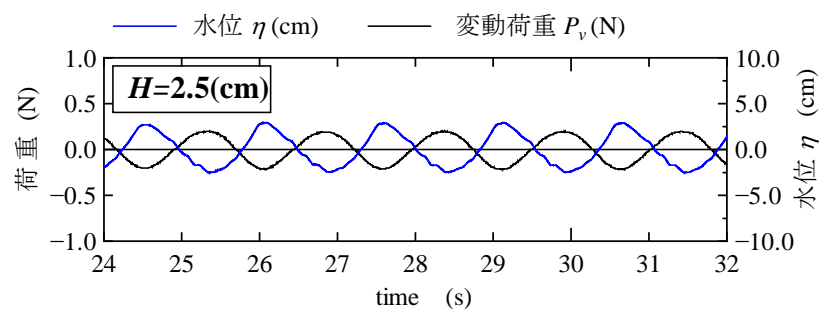

図-23 変動荷重の波形（規則波 : 1回目）

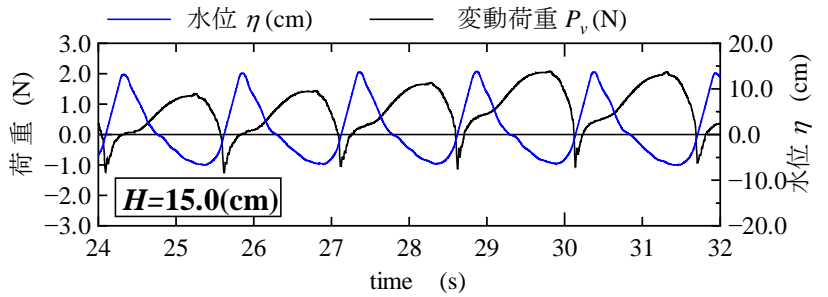

（左図 : $H=2.5 \mathrm{~cm}$, 右図 : $H=15.0 \mathrm{~cm}$ )

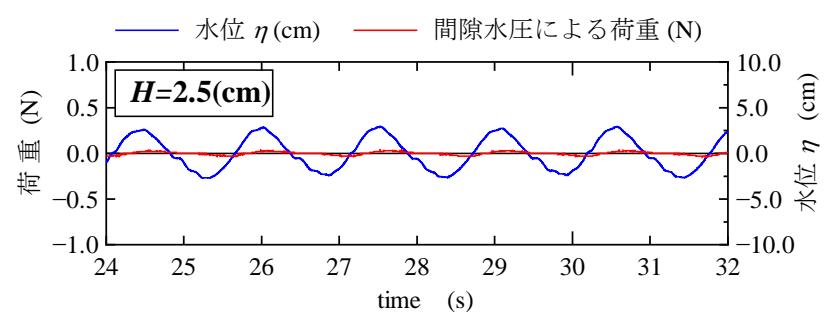

図-24 間隙水圧の荷重の波形（規則波 : 1 回目）

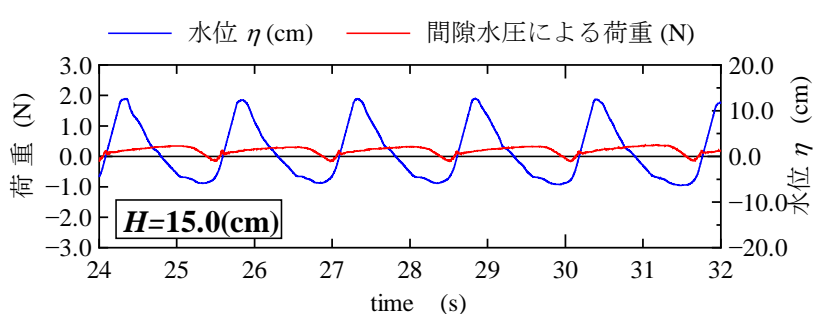

（左図 : $H=2.5 \mathrm{~cm}$, 右図 : $H=15.0 \mathrm{~cm}$ )

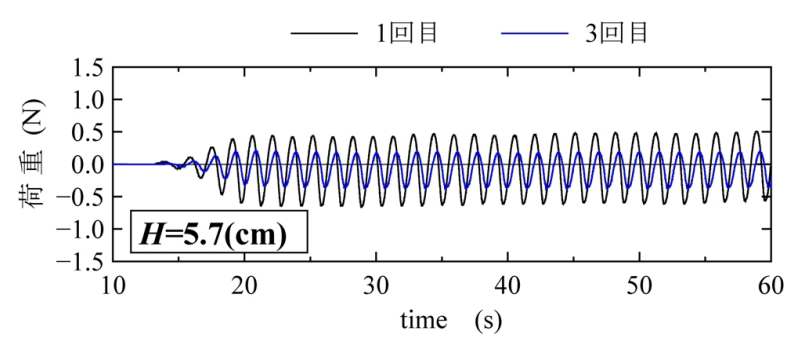

図-25変動荷重波形の上下方向への振動（規則波）

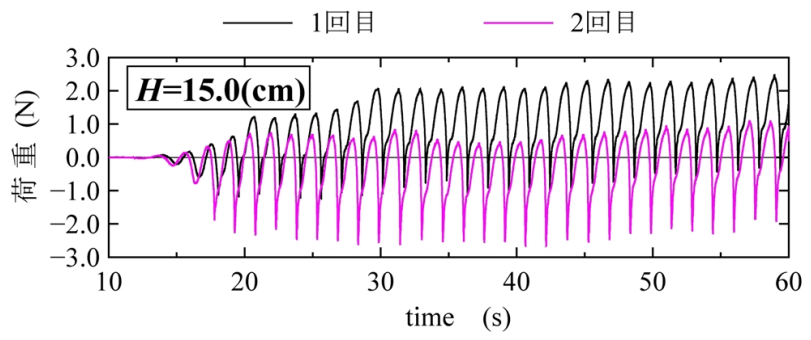

(左図 : $H=5.7 \mathrm{~cm}$, 右図 : $H=15.0 \mathrm{~cm}$ )
$11.3 \mathrm{~cm}$ (現地量で 4.8m〜9.5m) の 3 種類とした. ここで $H_{13}=11.3 \mathrm{~cm}$ (現地量で $9.5 \mathrm{~m}$ ) は，四脚ブロックの最大級 である 80t 型の安定限界波高相当である。また，周期は 1.53s（現地量で 14.0s）の 1 種類とし，その值は四脚ブ ロックの大型（50t 型～80t 型）の施工実績を調査して決 定した.

測定方法は，5種類の波高による計測を 1 サイクルと して，規則波の条件のみブロックの積み替えを行いなが ら 5 サイクル実施した。.また，間隙水圧による荷重が変 動荷重に与える影響を調査するため，測定対象ブロック の周りを立方体に組んだ金網で囲い，周囲のブロックと 接触しないよう分離し, 間隙水圧による荷重のみがロー ドセルに伝達される装置（図-22）を使用した実験も規 則波のケースにて実施した.

\section{(2) 規則波の実験結果}

図-23，図-24 に規則波実験における $H=2.5 \mathrm{~cm}$ と $H=15.0 \mathrm{~cm}$ の変動荷重の波形と間隙水圧の荷重波形を示 す.ここで，図の縦軸は荷重の初期值からの変動荷重を 示しており，プラス側は最下層ブロックに対して鉛直下 向き方向の荷重を示しており，マイナス側は鉛直上向き 方向の荷重である.

まず間隙水圧による荷重と変動荷重の波形を比較する

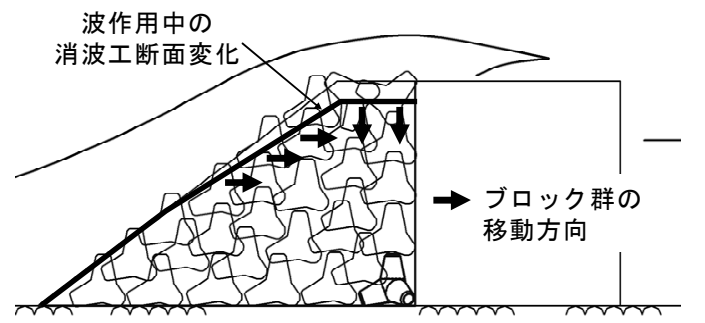

図-26 波作用中の消波工断面変化

と，間隙水圧による荷重は変動荷重に対して十分小さい ことがわかった：このことから，最下層ブロックに作用 する変動荷重は, 間隙水圧による荷重の影響はほとんど 無いと考えることができる.

次に図-23 の水位波形と変動荷重の波形を比較すると， $H=2.5 \mathrm{~cm}$ の変動荷重波形は周期的な正弦波振動となって おり，水位波形とほぼ完全な逆位相の関係となっている. 一方, $H=15.0 \mathrm{~cm}$ の波形は水位が上昇すると荷重が減少 し，逆に水位が低下すると荷重が上昇するという現象は $H=2.5 \mathrm{~cm}$ の時と同様であるものの, 波形自体は完全な逆 位相とはなっていない. 特に, 水位上昇がピークとなる 時間帯前後で両者の波形には違いが生じている.これは， 波高が小さい場合の変動荷重は水位変動による浮力の増 減が支配的になるが，波高が大きくなると波力による接 

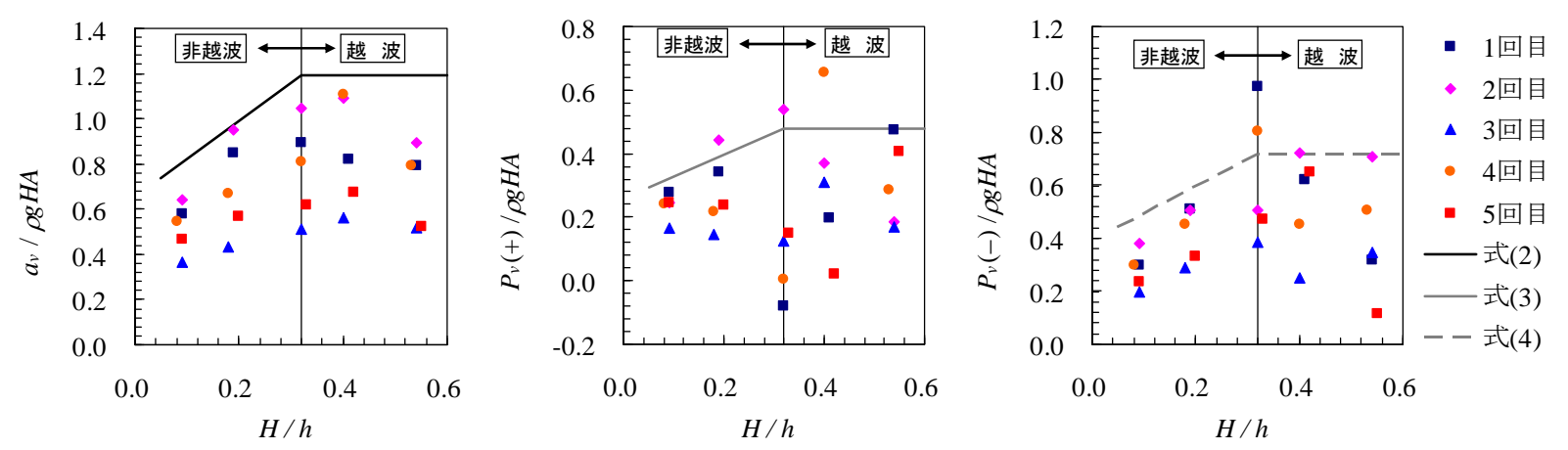

図-27 変動荷重と $H / h$ の関係 (左図 : $a_{v}$, 中央 : $P_{\downarrow}(+)$, 右図 : $P_{\downarrow}(-)$ )

触力の増減も影響しているためと考えられる.この影響 はブロックを鉛直上向き方向に押し上げる力が作用する 時（荷重波形が負の值となる時）に顕著に現れている.

図-25 は, $H=5.7 \mathrm{~cm}$ と $H=15.0 \mathrm{~cm}$ の実験開始から $T=60 \mathrm{~s}$ までの変動荷重波形を示したものである. $H=5.7 \mathrm{~cm}$ のケ 一スは，回数によって荷重の大きさ（振幅）に差はある ものの周期的な正弦波振動である. 荷重の差は, 1 回ご とに模型の積み替えを行っているため, 測定ブロックと 周囲のブロックとの初期の接触状態が異なることによる. しかし, $H=15.0 \mathrm{~cm}$ では, それ以外に変動荷重波形全体 が上方向，または下方向にシフトしていく傾向が見られ た。この現象は越波が始まる $H=9.0 \mathrm{~cm}$ から生じ，造波開 始 30sec 後付近から顕著に見られた. これは, 波作用中 にブロックの微動によって消波工断面が徐々に変化し始 め（図-26），これにより波作用前のブロック群の自重 による上載荷重の伝達経路（図-13）が時間とともに変 化したことが理由と考えられる。しかし，本研究におい て，波作用中の消波工断面変化による上載荷重の経時変 化量は変動荷重として定義していない. よって, 造波開 始 $T=30 \mathrm{~s}$ 付近までは波作用によって消波工断面が変化し ない，すなわち，波作用前の上載荷重が変化しないもの とみなし，この区間の波形のうち5波を変動荷重の対象 とした. ブロックの微動による上載荷重の経時変化量は, 今後設計用值を決定寸る際に部分安全係数（荷重係数） 等で考慮することとしたい.

図-27 は，変動荷重波形の両振幅 $a_{v}$, 波形の山の高さ $P_{\vee}(+)$, および波形の谷の高さの絶対值 $P_{\mathrm{v}}(-)$ (図-28) と 波高の関係を示す. 図の縦軸は $a_{v}, P_{v}(+)$, および $P_{v}(-)$ を最下層ブロックを上面から見た時の投影面積 $A$ （図29）に波高相当の圧力 $\rho g H$ を乗じた值で無次元化したも のである。また，図の横軸は波高 $H$ を設置水深 $h=28.5 \mathrm{~cm}$ で無次元化した波高水深比である. 図中のプロ ットは，水位波形が安定した時間（造波開始加ら約 24s 後）から 5 波を対象としたときの平均值であり，2 本の 折れ線で構成された実線は式(2), 式(3)および式(4)であ る.

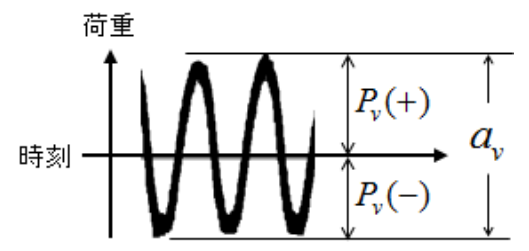

図-28 変動荷重 $P_{v}(+), P_{v}(-)$ と変動荷重の振幅 $a_{v}$

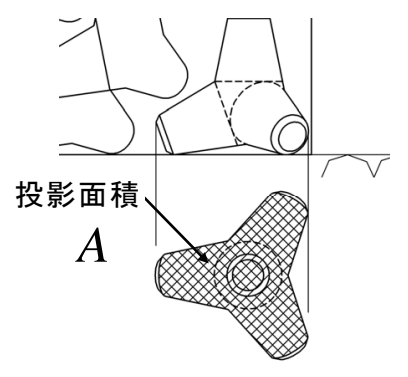

図-29 ブロックの投影面積 $A$

まず $a_{v}$ の值に着目すると, 試行ごとの傾向は同じで あるがばらつきが生じている.これは，1 回ごとに模型 の積み替えを行っており, 測定ブロックと周囲のブロッ クとの初期の接触状態が異なることによる.

$P_{v}(+)$ および $P_{v}(-)$ の值は, 波高水深比 $H / h=0.32$ $(H=9.0 \mathrm{~cm})$ を境に変動荷重のばらつきが拡大しており, かつ波高ごとの值の大小関係も $a_{v}$ とは異なっている. これは，ブロック積み替えによるばらつきもあるが，大 きく影響したのは，前述した消波工断面の変化であると 考えられる. 消波工断面の変化は表層ブロックの姿勢変 化でもあり，姿勢が変化すれば波圧を受ける面（受圧面 積）も変化する. 消波工断面変化の状態は波高ランク毎 でばらつくと考えられることから, 表層ブロックに作用 する波力もばらつくことになる．また，消波工断面変化 は波力による接触力の伝播経路（図-20）も変化させる. これらの影響が, 変動荷重のばらつきを拡大させたと推 測される.

また，波高水深比 $H / h=0.32$ 以下では $a_{v}, P_{v}(+)$, および $P_{\sqrt{ }(-)}$ ともに単調増加傾向にあるが，これを超えた付近か らは一定，あるいは減少に転じる傾向を示している。 こ 
れは，2 つの理由が考えられる，まずは，図-30 のよう に，越波まで波高が大きくなると消波工の斜面を遡上す る流れが生じるため, これにより表層の消波ブロックに 作用する波力の向きが変化し, その結果, 対象位置のブ ロックの鉛直方向荷重の変化量が小さくなったためと考 えられる．次に，波高の増加にともない，波の非線形性 によって峰が細り, 谷がフラットになることで浮力の変 化が小さくなったことが考えられる，よって，越波段階 から変動荷重が一定，あるいは減少に転じるのは，消波 工を遡上寸る流れと波の非線形性の影響が支配的となっ て現れたと推測される.

次に, 図中の $H / h=0.32$ を境界に引かれた 2 本の折れ線 であるが，これは変動荷重が $H / h=0.32$ 以下は波高ととも に単調増加し，それ以降は一定值になると仮定して定め たものである.

まず $a_{v}$ は定数 $C_{1}, C_{2}$ を用いて式(2)で表すこととした. そして，P $\left.P_{v}+\right)$ は式(2)に定数 $C_{3}$ を乗じたもの（式(3)）と し，P、(-)は式(2)から式(3)を減じることで表せるものとし た（式(4)）。ここで, 定数 $C_{1} \sim C_{3}$ は, 本研究では 2 本 の折れ線の下側に $a_{v}, P_{v}(+)$, および $P_{v}(-)$ の全データの 90\%以上が入るように決定した。

以上の規則波の実験結果より，最下層ブロックに作用 する変動荷重は越波時と非越波時で傾向が変化する特性 を有していることが明らかとなり，かつその值は波高相 当の圧力 $\rho H$ とブロックの投影面積 $A$, および波高水深 比 H/h を用いて定式化できることが示された.

$$
\begin{aligned}
& \frac{a_{v}}{\rho g H A}= \begin{cases}C_{1}(H / h)+C_{2} & (0.05<H / h \leq 0.32) \\
0.32 C_{1}+C_{2} & (H / h>0.32)\end{cases} \frac{P_{v}(+)}{\rho g H A}=C_{3}\left(\frac{a_{v}}{\rho g H A}\right) \\
& \frac{P_{v}(-)}{\rho g H A}=\left(1-C_{3}\right)\left(\frac{a_{v}}{\rho g H A}\right) \\
& \text { ただし, } C_{1}=1.70, C_{2}=0.65, C_{3}=0.40
\end{aligned}
$$

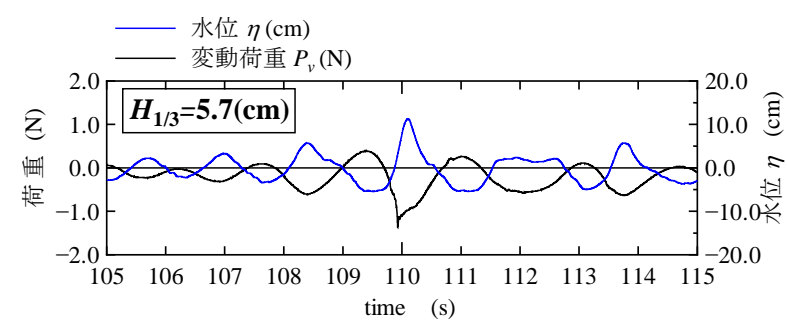

図-31 変動荷重の波形（不規則波）

\section{（3）不規則波の実験結果}

不規則波作用時の変動荷重波形を図-31 に示寸．水位 波形と変動荷重の波形を比較すると, $H_{13}=5.7 \mathrm{~cm}$ の変動 荷重波形は水位波形とほぼ逆位相の関係となっている. 一方, $H_{13}=11.3 \mathrm{~cm}$ の波形は水位が上昇すると荷重が減少 し，逆に水位が低下寸ると荷重が上昇するという現象は $H_{13}=5.7 \mathrm{~cm}$ と同様であるが，波形自体は不規則波におい ても完全な逆位相とはなっておらず，水位上昇がピーク となる時間帯前後で両者の波形に違いが生じている.こ のことから，不規則波も規則波と同様，波高が小さい場 合の変動荷重は水位変動による浮力の増減が支配的にな るが，波高が大きくなると波力による接触力の増減も影 響していると言え，この影響はブロックを鉛直上向き方 向に押し上げる力が作用する時（荷重波形が負の值とな る時）に顕著に現れている.

図-32 は規則波の結果（図-27）と同様に，縦軸は変動 荷重の両振幅 $a_{v}$, 変動荷重 $P_{v}(+)$ およよ゙ $P_{v}(-)$ を有義波 $H_{13}$ 相当の圧力 $\rho g H_{13}$ とブロックの投影面積 $A$ を乗じたもの で無次元化している．横軸は有義波高 $H_{13}$ を設置水深 $h$ で無次元化した波高水深比である. 図中の最大值，1/10 最大值，および $1 / 3$ 最大值は，1,000 波（全データ）を解 析対象としたときのデータのそれぞれ最大值，最大值か ら並び替えた時の上位 $1 / 10$ の平均值，および上位 $1 / 3$ の 平均值である. また，図には式(2)〜式(4)も図示してい る. なお，式中の $H$ は $H_{13}$ に置き換えている.

図より, 波高水深比 $H_{13} / h=0.32$ 以下で変動荷重は増加 傾向であり，それを超えると一定もしくは減少傾向にあ り，規則波の結果と同様であった。また式(2)〜式(4)に ついて, $a_{v}$ の $H_{13} / h=0.32$ 以下のデータの増加傾向は規則 波とほぼ同様の結果を示していたため，式(2)中の $C_{1}$ は

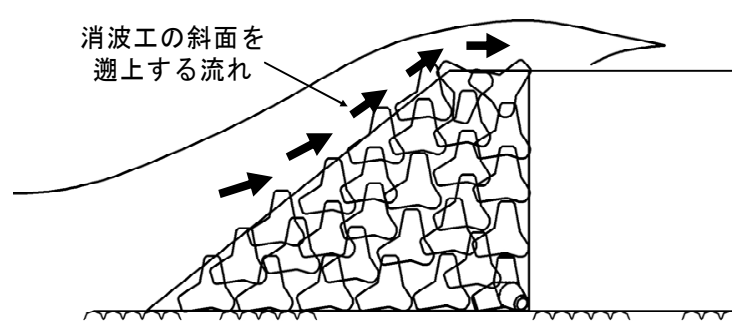

図-30 消波工の斜面を遡上する流れ（越波時）

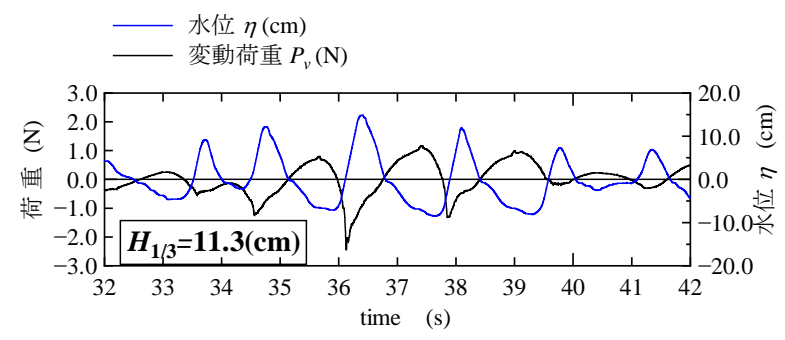

(左図 : $H_{13}=5.7 \mathrm{~cm}$, 右図 : $H_{13}=11.3 \mathrm{~cm}$ ) 

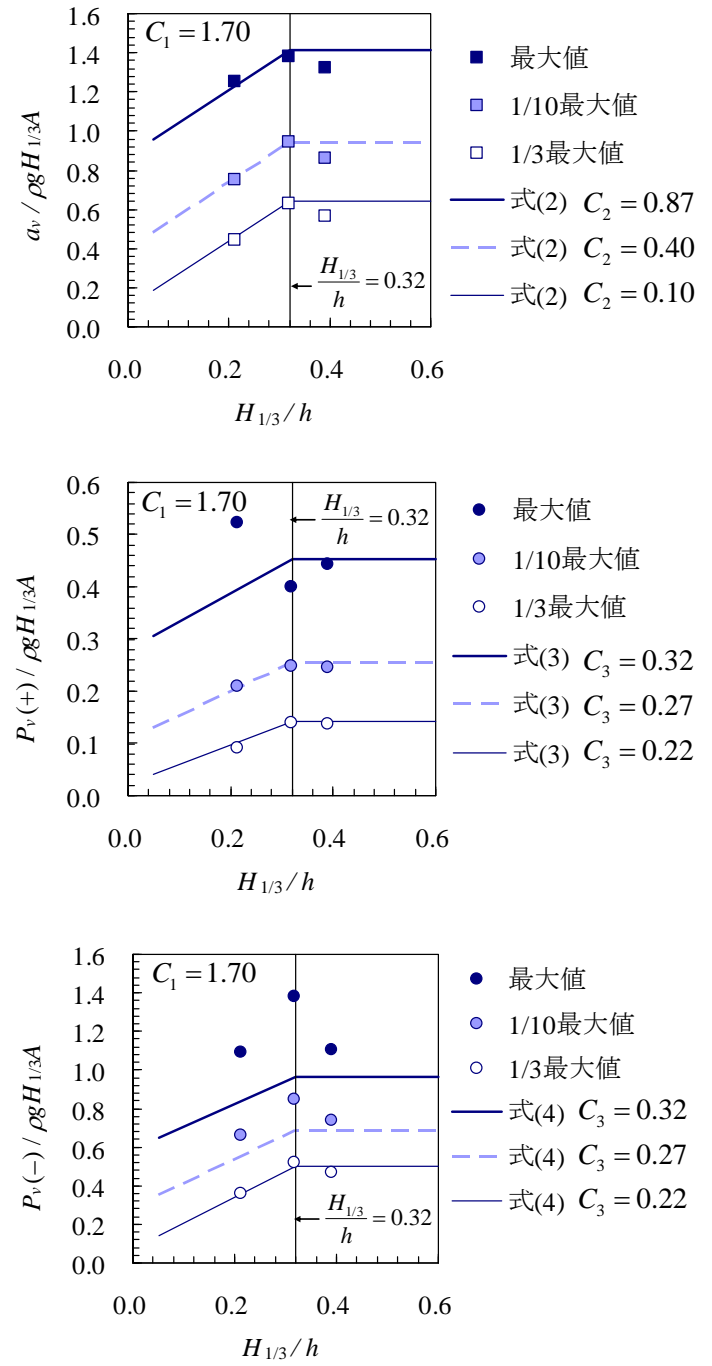

図-32 不規則波作用時の変動荷重と $H_{13} / h$ の関係（上段 : $a v$, 中央 : $P_{v}(+)$, 下段 : $\left.P_{\downarrow}(-)\right)$

1.7 とした． $C_{2}$ および $C_{3}$ は， $a_{v}$ および $P_{v}(+)$ のれぞれ最 大值， $1 / 10$ 最大值および $1 / 3$ 最大值データにフィットす るよう決定した．ただし， $P_{V}(+)$ の最大值データはばらつ きが大きいため, この場合のみ $C_{3}$ は $H_{13} h=0.39$ $\left(H_{13}=11.3 \mathrm{~cm}\right)$ のデータの上限を通るように決定した.

以上より，不規則波においても規則波の結果と同様， 変動荷重は有義波 $H_{13}$ 相当の圧力 $\rho g H_{13}$ とブロック投影 面積 $A$ ，および波高水深比 $H_{13} / h$ を用いて定式化できる ことが示された．なお，変動荷重は消波工の天端高によ って傾向が異なると考えられるため, 本研究にて提案し た式は，天端高が防波堤の安定の検討に用いる有義波高 $H_{13}$ の 0.6 倍程度の高さ，もしくはブロックの安定限界 波高の 0.6 倍程度の高さに限り適用可能である.

\section{4. まとめ}

消波ブロックの構造強度の評価手法を確立するため,
消波ブロック被覆堤を対象に消波工の最下層に設置され る消波ブロックに作用する静穏時の上載荷重や波作用下 の変動荷重の特性を明らかにするとともに，これら荷重 の定式化の可能性を探ることを目的に，上載荷重の測定 実験を実施した. 本研究にて得られた結論を以下に示寸.

1) 静穏下における最下層ブロック単体に作用する上載 荷重の分布は，ブロックの形状や最下層の設置位置， およびブロックの大きさによらずガンマ分布で近似 できる特性を有していることが明らかとなった。

2) 静穏下における上載荷重の平均值は，水面の位置や 消波工の相対密度，浮力，消波工高さおよび最下層 ブロック単体の支配面積を用いて定式化できる.

3) ブロック単体の立体形状や部材断面形状の違いは, 試行による積み上げ姿勢の方向の違いや，ブロック 相互の接触状態の違い，および個々の空隙のばらつ きを生じさせ，上載荷重分布の変動係数に影響を及 ぼす。

4) 鉛直壁側に設置される最下層ブロックの上載荷重分 布の平均值は，その他の位置の平均值よりも大きか った.これは，鉛直壁側のブロックは，壁の影響で 上層ブロックからの荷重が下層ブロックの全方向に 分散して伝達されず鉛直下向きに分散されやすくな ったことが理由と考えられる.

5）小縮尺と大縮尺の模型実験の結果，大縮尺での上載 荷重分布の平均值は小縮尺よりも増加し，変動係数 は減少した。これは，ブロック寸法を大きくしたこ とで見かけ上の表面粗さが小さくなり，これが接触 面近傍で局所的な滑りが生じさせ，その結果，ブロ ック同士の接触によって形成される隙間が均一化さ れたことが理由と考えられる。

6) 最下層ブロックの群体に作用する上載荷重分布の変 動係数は, ブロック単体の $1 / 4$ 程度にまで大きく減 少した。 これは，ある最下層ブロックに着目した時 の試行の結果は，隣接するブロックの試行に影響を 及ぼしていることを意味している.

7) 波作用下における最下層ブロックに作用する変動荷 重は，消波工の間隙水圧による荷重の影響はほとん ど無いことが規則波の実験にて明らかとなった。ま た，波高が小さい場合は浮力の増減が支配的であり， 波高が大きい場合は浮力以外に波力がブロックを伝 播して作用する接触力の増減が支配的となる特性を 有していることが規則波ならびに不規則波の実験に て明らかとなった。

8) 波高の増加に伴い，変動荷重のばらつきが拡大した． これは，表層ブロックの姿勢変化により波圧を受け る面（受圧面積）にばらつきが生じたことと，消波 工断面の変化によって波力による接触力の伝播経路 が変化したことが影響したと考えられる. 
9) 変動荷重は規則波，不規則波ともに，波高の小さい 非越波時は波高の増大とともに単調に増加するが, 越波が起きた段階あたりからは一定，または減少傾 向に転じた。これは，消波工を遡上する流れと波の 非線形性の両者の影響が支配的となって現れたと推 測される.

10）規則波および不規則波の実験から，波作用下におけ る最下層ブロックに作用する変動荷重は波高相当の 圧力，または有義波相当の圧力と最下層ブロックを 上方から見た時の投影面積，および波高水深比を用 いて定式化できる.

\section{参考文献}

1) Noboru, S., Iwanami, M., Yamamoto, M. and Nishiwaki, I.: Structural Performance Evaluation of New-type Wave Dissipating Concrete Block, Proceedings of the 31st International Conference on Coastal Engineering, ASCE, pp.3436-3448, 2008.

2) 有川太郎，池辺将光，大菩菜々子，黒田豊和，織田 朋哉，下迫健一郎：消波ブロックによるケーソン壁 面押し抜きせん断破壊に関寸る研究，港湾空港技術 研究所, Vol.44, No.1, 2005.3.

3) 山口貴之, 別府万寿博, 大野友則 : 衝撃砕波を受け る消波ブロックの直立壁への衝突現象に関する実験 的研究, 海岸工学論文集, Vol.50, pp.711-715, 2003.

4) 社団法人日本港湾協会 : 港湾の施設の技術上の基 準・同解説（下巻），pp.819，2007.11.

(2016. 11. 11 受付)

\title{
SURCHARGE LOAD ACTING ON THE BLOCK IN THE BOTTOM-LAYER OF BREAKWATER COVERED WITH WAVE-DISSIPATING CONCRETE BLOCKS
}

\author{
Satoshi NOBORU, Shin-ichi KUBOTA, Akira MATSUMOTO, Nobuhiro CHIJIWA, \\ and Mitsuyasu IWANAMI
}

A structural performance evaluation method for wave-dissipating concrete blocks has not yet been established. In this study, surcharge load acting on the block sitting in the bottom-layer of breakwater covered with wave-dissipating concrete blocks was examined through model experiments against permanent action and variable wave action in order to clarify the characteristics of surcharge load and to investigate the possibility of the formulation of surcharge load. Based on the results of model experiments, surcharge load by permanent action could be approximated by a Gamma distribution. And, surcharge load by wave action was affected by wave overtopping. The formula for estimating surcharge load by permanent action and wave action were proposed. 